\title{
A historical evaluation of the Battle of Pyongyang in the Korean War through a tactical fault analysis
}

\author{
Jisoo Park ${ }^{*}$
}

The purpose of this study is to consider the 'Battle of Pyongyang' of the I Corps during the Korean War from the historical point of view. This study argues that there are some limit to the U.N. military's 'Battle of Pyongyang' that it failed to maximize the benefits of recapturing Pyongyang, the capital of North Korea. And this can be evidenced by some notable tactical faults that the 1 Corps has caused in 'Battle of Pyongyang'. First, the I Corps (America's First Corps) excessively delayed its time during the 'Battle of Pyongyang'. Second, the 24th U.S. Infantry Division was excluded from the 'Battle of Pyongyang' and failed to concentrate its combat capabilities. Third, I Corps did not besiege the North Korean army, and North Korean could escape from Pyongyang. The I Corps was fiercely competitive to arrive in Pyongyang first, and failed to make efforts to contribute to higher-level operations. In conclusion, this study finds some lesson from the I Corps's tactical faults behind the glory of 'Battle of Pyongyang'.

(1) T) This work is licensed under a Creative Commons Attribution 4.0 International License.

* (First Author) ROK Army Training \& Doctrine Command, Military Staff College, Major, 151wkrwjs@gmail.com 
Keywords : Korean War, battle of Pyongyang, battle of Geumcheon, battle of Sariwon, U.N. forces' advance to Pyongyang 


\section{I. 서론}

전쟁을 구성하는 수많은 전투는 각자 독립적인 것이 아니라, 상호 유기적으로 연결되어 있다. 6 • 25전쟁 기간 중 총 233회의 크고, 작은 전투가 발생하였고(Nam, 2001), 이들은 각각 독립된 전투이 면서 6 - 25 전쟁 자체에 큰 영향을 미칠 정도로 매우 중요한 가치를 지니고 있다. 따라서 개별 전 투는 단순히 그 자체만으로 성공 혹은 실패를 평가하기 어렵다. 각각의 전투들은 내부의 수많은 과 정과 맥락으로 연결되어 있기 때문이다. 따라서 전투에 관한 연구는 내부의 수많은 과정과 절차에 대한 분석, 그리고 결과에 미친 영향 등을 종합적으로 고려하여 평가해야 한다. 그러나 $6 \cdot 25$ 전쟁 중 발생한 수많은 전투는 분석하는 관점에 따라 다양하게 평가됐다. 대표적인 예로 평양탈환 전투 가 우리에게 어떻게 기억되고 있는가를 살펴볼 필요가 있다. 평양탈환 전투는 국군이 승리에 대한 열망과 의지로 미군보다 앞서 적의 심장부인 평양에 입성함으로써 전 장병이 1 계급 특진의 영광을 안은 전투로서 기억되고 있다. 특히 미 제 1 기병사단은 평양으로 진격하는 과정에서 금천과 사리원 등지에서 북한군 약 3 개 사단 이상의 부대를 궤멸 혹은 포로로 사로잡으면서 혁혁한 전공을 세우기 도 하였다. 하지만, 평양탈환 이후 전쟁의 양상을 고려해볼 때, 평양탈환 전투 과정에서 찾을 수 있 는 여러 아쉬움은 작지 않으며, 이는 분명한 '과오'로 여겨질 수 있을 만한 단서라고 할 수 있다.

과오(過誤, mistake, error, fault)의 사전적 정의는 '부주의나 태만 따위에서 비롯된 잘못이나 허 물'을 의미한다. 법률적으로는 ‘부주의로 인하여, 어떤 결과의 발생을 미리 내다보지 못한 일’로 정 의되고 있다.1) 군사용어 사전에는 명확히 정의되지 않았지만, 군에서 쓰이는 과오라는 용어는 교리 혹은 규정, 절차대로 이행하지 않음으로써 피해를 야기하거나 작전 혹은 전투를 그르칠 수 있는 상 황에서 사용되는 용어로써 사전적 의미와 유사하게 통용되고 있다. 본 연구에서는 명확한 분석을 위하여 과오에 대해 아래와 같이 정의하였다.2)

(1) 상급부대의 작전 혹은 의도에 기여하지 못하는 것

(2) (적보다 유리한 상황에도 불구하고) 적이 작전 의도를 달성하도록 허용하거나, 혹은 이를 거 부하지 못하는 것

유엔군의 평양탈환 전투는 북한의 심장인 평양을 점령함으로써 얻을 수 있는 이점을 최대한 살 리지 못했다는 한계를 지닌다(Nam, 2001). 이는 유엔군이 평양진격 간 일으킨 몇 가지 주목할 만한 전술적 과오로써 뒷받침될 수 있다. 그 중 첫 번째는 유엔군이 평양진격 간 공격 기세를 유지하지 못하고, 과도하게 시간을 지체하였다는 것이다. 유엔군은 적의 강력한 저항이 충분히 예상되는 기

1) 국립국어원 표준국어대사전(https://stdict.korean.go.kr/search/searchView.do)(검색일자 : 2019. 6. 14.).

2) 이외에도 ‘작전(혹은 전투)에 영향을 미칠 정도의 피해를 가져올 만한 것' 또한 과오로 정의할 수 있으나, 이는 자료의 제한으로 인해 특정 과오 행동과 피해 결과 간의 인과관계를 명확하게 밝히기 어렵다는 한계가 있다. 
동로를 주공 방향으로 택하였고, 이에 따라 금천점령까지 미 제 1 기병사단의 진격속도는 공병의 지 뢰 제거 속도와 같았다. 결과적으로 유엔군은 금천을 점령하는 데 5일이나 소모하게 되었고(Kim, 1986), 이는 북괴군의 지연방어 목적을 달성하도록 허용하게 된 중요한 계기가 되었다. 유엔군의 평 양진격이 지체되는 동안 평양의 김일성과 박헌영은 이미 평양을 빠져나가 평더화이(彭德懷)에게 중국군의 개입을 요청함에 따라 전쟁의 양상은 더욱 복잡한 성격을 띠게 되었다(Park, 2009).

두 번째는 미 제 24 사단의 평양탈환 전투 배제이다. 미 제 1 군단장은 평양탈환 작전에 세 개 사단 중 두 개 사단만 참여시킴으로써 공격 기세 유지와 전투력 집중에 실패하였다. 결과론적으로 평양 탈환에 성공하였기 때문에 주목받지는 못하였지만, 1 개 사단이라는 작지 않은 규모의 전투력이 주 요 작전에서 배제되었다는 것은(On, 2010, p. 796-797; War Commemoration Service Society, 1992, p. 283-284) 전투력 집중이라는 공격작전의 준칙이 제대로 지켜지지 않았다고 할 수 있다.

세 번째는 북괴군의 퇴로 차단을 위한 포위 기동 실패이다. 국군 제 1 사단은 보·전 - 포 협동 공 격으로 꽤 빠른 진격속도를 보였기에, 평양 입성에 투입하기보다는 평양 북방에 대한 퇴로를 차단 하는 임무를 수행했었더라면 하는 아쉬움이 남는다. 특히 당시 맥아더 사령관이 평양 북방에 대한 포위를 염두에 둘 정도로 평양 북방의 퇴로를 차단하는 것은 유엔군에게 있어 매우 중요한 과업이 었다. 하지만, 미 제 1 군단 예하 부대들은 평양 입성에 대한 과도한 경쟁심에 불탔을 뿐, 상급부대 작전에 기여하기 위한 지혜를 발휘하지는 못하였다.

이와 같은 과오는 평양탈환 이후 전쟁 양상이 어떻게 전개되었는가를 고찰해 봄으로써 보다 분 명하게 평가될 수 있다. 평양탈환 이후 자신감을 얻은 유엔군은 전진한계선을 상향 조정하고, 압록 강까지 북진하지만 결국 중국군의 개입으로 한강 이남까지 철수하게 되는 상황에 이르게 된다. 이 러한 사실을 통해 평양탈환 전투가 조금 다른 양상으로 전개되었더라면, 이후의 전쟁 양상에 어떠 한 변화가 있었을까 하는 문제를 제기할 수 있다. 따라서 본 연구는 아래와 같은 세 가지 측면에서 평양탈환 전투에 대한 평가가 엇갈릴 수 있어 평양탈환 전투의 의의를 재평가하고자 한다.

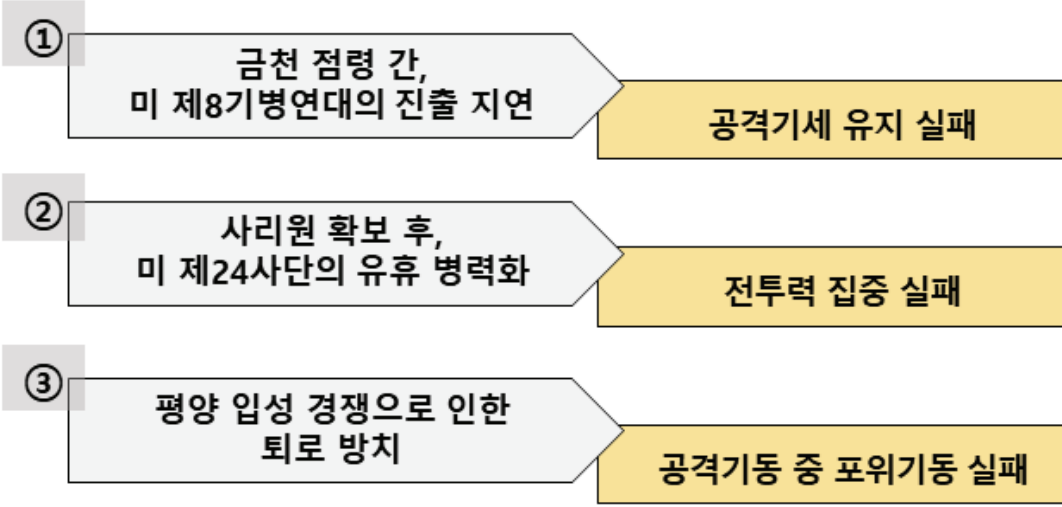


연구 질문은 '결과론적으로 평양이라는 전략적 중심을 무너뜨렸다는 이점을 최대한 살리지 못한 유엔군의 전술적 과오는 무엇이었는가'이다. 본 연구의 목적은 평양탈환 작전에 대한 전투사를 1 2차 사료를 통해 재구성함으로써, 이후 전쟁의 양상에 변화를 가져다줄 수 있었을 만한 전술적 과 오를 밝히는 데 있다. 다만, 본 연구가 평양탈환 전투의 성공을 부정하는 것이 아니라, 성공적인 결 과에 가려져 주목받지 못했던 과오들을 통해 전투사를 재평가함으로써 향후 발전을 위한 교훈을 도출하는 데 그 목적이 있음을 밝혀둔다.

평양탈환 전투 관련 기존 연구를 고찰했을 때, 대부분의 연구는 평양탈환 전투의 한계를 구체적 으로 분석하지 못하고 성공 혹은 승리한 전투로 평가하였다(Institute for Military History, 2009, p. 383-385; Nam, 2001; On, 2010, p. 113-128; War Commemoration Service Society, 1992). 특히, 진격 과정에서 전술적 과오로 여겨질 만한 다양한 근거들은 적의 수도를 탈환했다는 고무적인 결 과에 따라 가려졌고, 그에 따라 긍정적 평가가 전투사 연구의 주류를 형성해왔다. 반면, 평양탈환 전투의 한계를 지적한 연구들도 일부 존재하였으나(ROK Army, 2013), 전쟁 혹은 작전적 수준에서 의 거시적 분석이 대부분이었고, 전투 과정 자체에서 한계 요인을 찾으려는 전투사적 관점의 시도 는 빈약하였음을 알 수 있었다. 따라서 평양탈환 전투에 대한 전투사적 고찰을 통해 특정 국면에서 의 전술적 과오가 차후 작전과 어떻게 연결될 수 있었는지를 살펴봄으로써 '작은 것이 결코 작지 않다’라는 교훈을 도출하는 것이 본 연구의 의의이다.

본 연구의 연구방법은 문헌연구이다. 6 - 25 전쟁에 관한 자료는 북한 자료를 제외하면 대부분 공개되어있으며, 이를 통한 많은 연구가 이미 진행되어왔다. 따라서 기존에 진행되어왔던 평양탈환 전투에 관한 $1 \cdot 2$ 차 사료들을 토대로, 평양탈환 전투 과정에서 발생한 여러 전술적 과오를 통해 평 양탈환 전투를 전투사적으로 재고찰하고자 한다. 구체적으로 1 차 사료인 평양탈환 전투 당시의 전 투 상보와 현재까지 연구된 2차 사료를 통해 평양진격에 있어서 더딘 진격속도, 미 24사단의 유휴 화, 평양 북부에 대한 퇴로 차단의 실패 등의 국면 속에서 세부 전투 수행과정의 전술적 과오를 도 출해 내겠다. 그리고 이를 통해 평양탈환 전투 이후의 상황과 연계하여 재평가를 시도하고자 한다. 연구 범위는 미 제1기병사단이 38도선을 통과한 1950년 10월 9일부터 평양탈환에 성공한 10월 20 일까지 약 11 일 간의 평양탈환 전투이다. 그중에서도 38 도선 통과부터 평양에 도달하기까지 미 제 1 군단의 평양진격 과정을 살펴볼 것이다.

\section{ㅍ. 1 단계 금천 공격 : 미 제8기병연대의 진출 지연}

\section{1 북괴군의 강력한 저항}

북괴군은 유엔군의 북진을 저지하기 위하여 3 개의 방어선을 구축하고 있었다. 제 1 선은 38 도선을 
따라 구축해 놓은 견고한 진지와 개인호, 교통호, 포상 및 철조망 등으로 구성된 방어선으로, 종심 은 약 $500 \mathrm{~m}$ 정도였다. 제 2 선은 이로부터 약 3 $5 \mathrm{~km}$ 후방 일대의 주요 고지와 지형지물을 따라 형 성되어 있었고, 후방의 주요한 지형을 중심으로 선정된 거점을 이용하여 제 3 선이 구축되어 있었다. 이처럼 3 개의 저지 진지를 축차적으로 구축한 북괴군은 38 도선 일대에서의 저항을 우선 시도하고, 이 저지선이 돌파될 때는 매설된 지뢰와 도로 차단을 통해 유엔군의 북진을 방해하면서, 잔류 병력 이 유격전을 전개하여 유엔군의 진격을 지연시킨다는 방어 계획을 수립하였다(On, 2001, p. 792). 미 제 1 군단장 밀번 소장은 개성 북방의 38 도선 방어진지 상에 배치된 4 개 사단 규모의 북괴군을 격파하면, 평양을 향한 북진은 비교적 수월할 것으로 보았다. 또한, 북괴군이 패잔병들을 수습 및 재편하여 견고한 축차 방어진지를 구축하기 전에, 일거에 목표를 점령하기 위한 신속한 북진이 무 엇보다 중요하다고 판단하였다(War Commemoration Service Society, 1992, p. 274). 따라서 그는 정면돌파보다는 기갑부대의 강한 충격력과 기동력의 이점을 최대로 살린 '우회기동에 의한 포위' 방법을 택하기로 하고 예하 부대에 아래와 같이 작전명령을 하달하였다(Institute for Military History, 1986, p. 59-62).

(1) 미 제 1 기병사단(배속 : 영연방 제 27 여단)은 군단의 주공으로서 개성 이남의 38 도선을 돌파하 여 금천 일대의 북괴군을 포위 섬멸한 후, 남천점 사리원 황주 평양 방향으로 진격하라.

(2) 미 제 24 사단은 군단의 좌측방을 엄호하고, 주력(군단예비)으로서 미 제 1 기병사단을 초월 공 격할 준비를 하라.

(3) 한국군 제 1 사단은 군단 우익으로서 고랑포 이남의 38 도선을 돌파한 이후, 군단의 우측방을 엄호하고, 시변리 신계 율리 평양 방향으로 진격하라.

금천 진격 간에는 미 제8기병연대가 사단의 중앙에서 개성-금천 도로를 따라 정면에서 공격하 고, 우측의 미 제 5 기병연대는 금천을 배후에서 공격하기 위하여 동쪽으로의 우회기동을 준비하고 있었다. 미 제7기병연대는 사단 좌측에서 예성강을 도하한 후 백천을 거쳐 금천 북방의 한포리라는 작은 마을로 진출하기 위한 준비를 하고 있었다. 즉, 미 제7기병연대가 한포리를 확보하여 적의 퇴 로를 차단하면, 미 제 8 기병연대와 제5기병연대에 쫓겨 북으로 퇴각하는 북괴군을 격멸하는 것이 미 제1기병사단의 계획이었다(Institute for Military History, 1986, p. 67-69; On, 2001, p. 794). 하지만 개성-금천 도로를 따라 중앙에서 정면공격을 개시한 미 제8기병연대의 진출은 매우 부진하였다. 연대는 전차를 선두로 10월 9일 12:00부로 공격개시선을 통과하였으나, 도로상에 많은 지뢰가 매설 되어 있어 공병대의 지뢰 제거반이 선두에서 지뢰를 제거해야 했기 때문이다. 즉, 미 제8기병연대 의 진출 속도는 공병대의 지뢰제거 속도와 같을 수밖에 없었다. 특히 북괴군이 매설한 지뢰는 주로 나무상자로 만들어져있어 탐지가 쉽지 않았으며, 공병대가 일일이 탐침 및 제거 과정을 거쳐야만 했다(Jung, 2007). 결국, 공격 첫날 연대는 개성 북쪽 $3.5 \mathrm{~km}$ 지점인 송악산을 탈취하고, 그 북쪽으로 
겨우 700m를 전진하는 데 그쳤다(Institute for Military History, 1986, p. 73).

미 제8기병연대는 공격 둘째 날인 10 월 10 일에도 적이 매설해 놓은 지뢰를 제거하는 데 많은 시 간을 빼앗겼다. 그리고 주변에 잠복하여 최후의 저항을 시도하는 북괴군으로부터 소화기 및 박격포 사격을 받아 진격이 더욱 부진하였다. 특히, 연대의 우측에서 1 번 도로를 따라 진출하던 제 3 대대는 봉명산 일대에서 북괴군 제 19 사단의 방어로 저지되어, 이날 3 대대의 진출 거리는 겨우 $2 \mathrm{~km}$ 에 그쳤 다. 그리고 연대의 좌측 대대로서 개성 서쪽 $7 \mathrm{~km}$ 지점인 토성리에서 경의선 철로를 따라 진격한 연대의 좌일선 제 1 대대 지역에서는 대대를 지원하던 미 제 70 전차대대 B중대의 전차소대가 38 도선 을 통과하였으나, 역시 북괴군이 매설해 놓은 대전차지뢰로 말미암아 진격이 계속 저지되고 있었다 (Institute for Military History, 1986, p. 73-75). 미 제8기병연대가 이처럼 고전을 겪는 사이, 좌 • 우측의 미 제 7 기병연대와 제 5 기병연대는 적의 저항에도 불구하고, 이를 잘 극복하며 목표지점으로 진격해 나가고 있었다. 그러나 미 제8기병연대는 북괴군의 완강한 저항으로 인해 거의 진출을 하지 못하였으며, 10 월 11 일에도 온종일 겨우 $2 \mathrm{~km}$ 를 전진하는 데 그쳤다. 게다가 연대가 두석산 가까이 진격할수록 북괴군의 저항은 점점 강해졌으며, 미 제8기병연대의 진출은 계속 지연되었다(Institute for Military History, 1986, p. 73-75; On, 2001, p. 794-795).

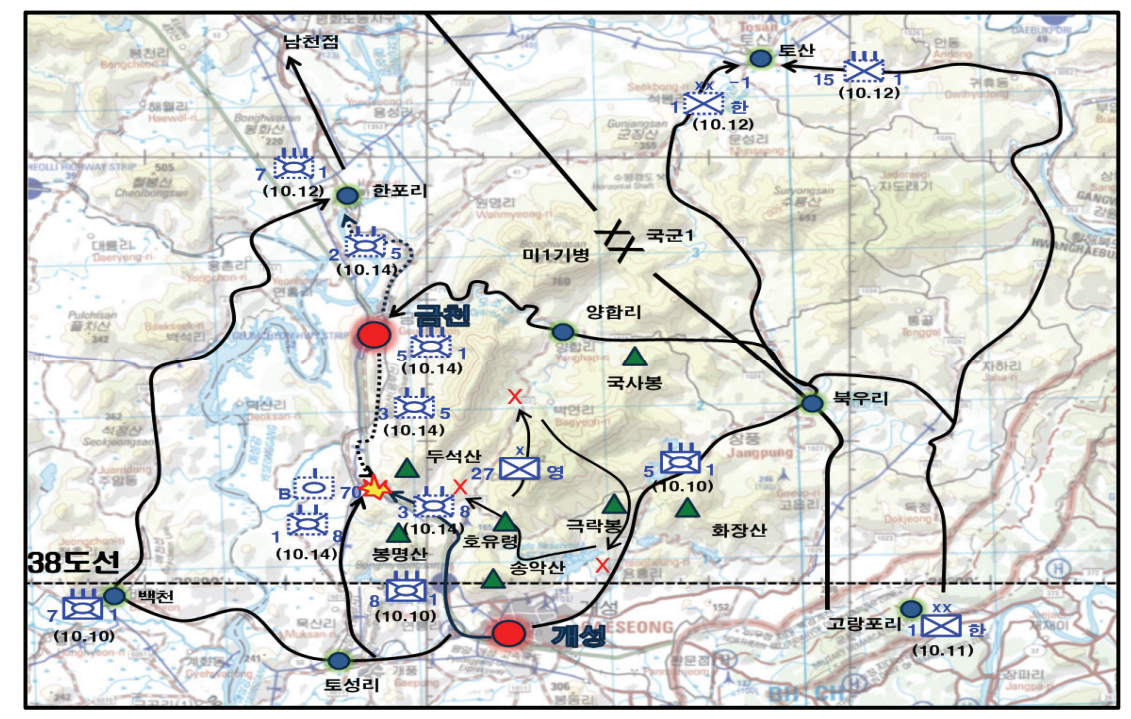

$<$ Figure $1>$ The Delay of $8^{\text {th }}$ Cavalry Regiment's advance to Geumcheon

위의 Figure 1 에서 보는 바와 같이, 미 제8기병연대는 10 월 14일까지 38도선으로부터 금천 방향 으로 겨우 절반밖에 진출하지 못한 상황이었다. 두석산을 앞두고 북괴군의 강력한 저항에 부딪혀 1 대대장(Robert W. Kane)이 중상을 입는 등 진격이 계속 지연되고 있었다. 이에 연대는 항공 및 포병의 지원을 요청하여 유엔군 전폭기 16 대에 의한 근접항공지원과 사단의 $155 \mathrm{~mm}$ 곡사포대대(미 
제99대대)까지 증원된 포격이 적진에 집중되었으나, 북괴군의 저항은 여전히 완강하였다(Institute for Military History, 1986, p. 79-80).

\section{2 영연방 제 27 여단의 증원 실패}

미 제8기병연대의 진출 지연으로 인해 사단 전체의 작전에 차질이 불가피해진 미 제 1 기병사단장 게이(Robert R. Gay) 소장은 영연방 제27여단이 사단의 중앙과 우측 연대 사이로 진격하도록 명령 하였다. 이에 따라 영연방 제 27 여단은 10 월 12 일 미 제6전차대대 B중대를 배속받아 불목동 서쪽 $7 \mathrm{~km}$ 지점에 있는 흥화리까지 진출하여, 그곳으로부터 국사봉 북쪽을 거쳐 양합동-금천으로 진격 하기 위한 기동로를 찾고 있었다(Institute for Military History, 1986, p. 80-81). 그러나 사단 관측 반의 실수로 인해 영연방 제 27 여단은 진격에 큰 차질을 빚을 수밖에 없었다. 그들이 사단 항공정찰 대의 유도에 따라 택한 도로는 겨우 우마차로에 지나지 않아 기동 자체가 제한되었다. 그리고 그마 저도 얼마 안 가서 산에 가로막혔다. 여단의 선봉 대대인 미들섹스(Middlesex) 대대는 되돌아 다른 계곡으로 들어가 보았으나, 길이 없기는 마찬가지였다. 여단은 다시 극락봉 남쪽까지 철수하여 도 보 병력만으로 미 제8기병연대의 지역으로 진입하였으나, 끝내 금천 전투에는 참여하지 못하게 되 었다(Institute for Military History, 1986, p. 81). 영연방 제27여단의 증원 실패로 인해 미 제8기병 연대의 진출은 더욱 어려워졌다. 미 제8기병연대는 금천 남방 두석산 일대에서 적의 강력한 저항으 로 여전히 고전 중이었다. 10 월 12 일부로 미 제 7 기병연대가 금천 북방의 한포리를 점령함으로써 적 의 퇴로를 차단하는 데 성공하였지만, 미 제 5 기병연대와 제8기병연대의 진출이 계속 지연됨에 따라 북괴군은 귀중한 시간을 더 획득할 뿐이었다(Institute for Military History, 1986, p. 81). 이 와중에 미 제 5 기병연대가 북우리 일대에서 국군 1 사단의 기동로를 무단으로 침범하는 과오를 범하면서 작 전 간 혼란을 가져오기도 하였다(Institute for Military History, 1986, p. 94; Jung, 2007, p. 142-143).

10 월 13 일 자정이 다 되어서야 미 제 5 기병연대의 선두부대인 제 2 대대가 금천 동측방에서 공격을 재개하여 금천 외곽을 방어하고 있던 북괴군을 소탕하고 금천 북반부를 점령하였으며, 그 뒤를 이 은 제3대대는 금천 남반부를 점령, 확보하였다. 하지만 미 제8기병연대는 여전히 금천 이남에서 진 출하지 못하고 있었다. 이 시기 북괴군은 주력이 미 제8기병연대의 진출을 저지하기 위해 결사의 저항을 하는 동안, 일부 병력은 퇴로를 차단당한 사실조차 모른 채 후방으로의 철수를 시작하였다. 한포리에서 퇴로를 차단하고 있던 미 제7기병연대는 항공지원을 받아 철수하는 북괴군을 사살 혹 은 포로로 사로잡기 시작하였다(Institute for Military History, 1986, p. 83-84; On, 2001, p. 795; War Commemoration Service Society, 1992, p. 281). 공격이 개시된 지 5일째인 10월 14 일, 미 제5 기병연대는 제 2 대대로 하여금 북진하여 미 제 7 기병연대와 연결하도록 하고, 제 3 대대에는 북상 중 인 미 제8기병연대와 연결될 때까지 남진하도록 하였다. 이에 따라 북서쪽으로 진격한 제 2 대대는 
정오경 한포리의 미 제 7 기병연대와 연결하는 데 성공하였고, 이에 따라 약 2,400 여 명의 북괴군들 은 뿔뿔이 흩어져 인근의 산악지대로 도주하였다(Institute for Military History, 1986, p. 86; On, 1992; War Commemoration Service Society, 1992, p. 281). 한편, 미 제8기병연대와 연결하기 위해 금천에서 남진하던 제 3 대대는 금천 남쪽 약 $6.5 \mathrm{~km}$ 지점에서 미 제 8 기병연대와 연결하였다. 이로써 미 제 1 기병사단의 금천점령 작전은 5 일 만에 종결되었다(Institute for Military History, 1986, p. 86). 이 작전으로 인해 유엔군은 5일이라는 시간을 지체하였다. 금천점령에 성공하였으나 계획보다 시간을 지체함으로써 결과적으로 신속한 추격과 전과확대의 호기를 놓쳤고, 북괴군의 방어 목적을 어느 정도 달성하도록 허용하고야 말았다.

\section{3 분석 및 평가}

미 제 1 기병사단의 금천 진격작전 간 보인 전술적 과오는 크게 두 가지로 볼 수 있다. 첫 번째 과 오는 공격 기동로 선정에 있다. 성공적인 공격작전을 위한 중요한 조건 중 하나는 방자가 예상하지 못한 '기습을 달성'하는 것이다. 당시 북괴군의 전투명령을 살펴보면 북괴군은 유엔군의 기갑부대 에 의한 금천 진출을 충분히 예상하였음을 알 수 있다. 북괴군은 장비의 기동이 가능한 주요 도로 를 위주로 병력을 배치하였으며, 예상 기동로에 대한 배비를 위해 상급부대에 지뢰와 같은 장애물 을 지속적으로 요청하였다. 송악산 일대를 점령한 107연대가 예하 부대들로부터 접수한 보고들에 의하면, 각 부대들은 반전차총과 지뢰, 반땅크(反Tank) 지대를 구성할 기재들을 지속적으로 요구하 였으며, 특히 개성으로부터 북쪽으로 이르는 대도로에 유엔군의 기계화 부대와 땅크들의 기동이 가 능할 것으로 예상하였다(Jang, 2001, p. 207-213, 268-279). 미 제1기병사단장은 금천으로 이르는 주 요 기동로에 대한 북괴군의 강한 대비를 충분히 예측했었어야 했다. 즉, 유엔군에게 유리하게 식별 된 기동로는 북괴군에게는 큰 위협이 될 것이며, 북괴군 역시 이에 대한 배비를 위해 노력한다는 것을 예측하는 데 어렵지 않았을 것이다. 하지만 미 제 1 기병사단은 개성에서 금천으로 이르는 가장 큰 도로인 1 번 도로에 미 제 70 전차대대 1 개 중대로 증원된 제 8 기병연대를 그대로 지향함으로써 적 의 강한 저항에 부딪혀 시간을 지체하였다. 이는 기습달성의 실패뿐만 아니라, 신속한 진격에 대한 상급부대의 요구를 충족시키지 못한 결정적인 과오라고 할 수 있다.

기동로 선정에 문제가 있었음을 뒷받침할 수 있는 또 하나의 근거는 장애물 봉착 시 이를 개척하 는 것 외에는 다른 방법이 없었다는 것이다. 미 제 1 기병사단은 적절한 우회로가 마련되지 않은 기 동로를 택함으로써 부대의 진격이 지체되었다. 장애물 운용 목적 중 가장 주요한 것은 저지와 지연 이다. 미 제8기병연대가 금천 진격 간 보여주었던 모습은 북괴군의 장애물 운용 목적에 그대로 부 합되는 것이었다. 즉, 북괴군이 장애물을 통해 유엔군의 진격을 지연시키고, 전쟁지도부와 부대들 이 후방으로 빠져나갈 수 있는 시간을 획득하게 해 주었다. 만약 개성-금천 간 1번 도로가 아닌, 동측의 5 번 도로에 더 많은 전투력을 할당하여 주 공격 방향으로 지향하였더라면 금천점령에 많은 
시간을 지체하지 않았을 것이다. 미 제 5 기병연대의 진출 방향인 5번 도로 좌·우 측방의 험준한 지 형을 이용한 북괴군의 강력한 저항이 예상되었으나, 실제 북괴군의 저항은 의외로 미약하였다 (Institute for Military History, 1986, p. 75). 따라서 개성-금천 간 1번 도로를 통해 적을 고착 및 견제하고, 5 번 도로를 통해 미 제 5 기병연대와 이를 후속하는 영연방 제 27 여단이 강한 충격력으로 금천방향을 지향하였더라면 금천전투의 결과는 충분히 달라졌을 것으로 예상할 수 있다.

두 번째 과오는 공격 기세를 유지하지 못하고, 전투력을 분산시켰다는 것이다. 미 제8기병연대가 두석산 일대에서 진격에 어려움을 겪는 사이, 미 제 1 기병사단장은 후속하던 영연방 제 27 여단으로 하여금 미 제 8 기병연대와 제 5 기병연대 사이로 진출하도록 하였다. 하지만, 영연방 제 27 여단은 기동 로마저 제대로 찾지 못하고 헤맴으로써 증원에 실패하였고, 배속받은 미 제6전차대대 B중대마저도 활용하지 못하였다. 결국, 영연방 제 27 여단이 금천점령 작전에 참여하지 못하게 됨으로써 공격 기 세 유지는 물론, 전투력 집중에도 실패하게 된 것이다.

북괴군은 유엔군의 북진을 저지하기 위하여 38 도선으로부터 평양에 이르기까지 3 개의 방어선을 설정하고 있었다. 북괴군은 지뢰 매설과 도로 차단, 거점 점령 등을 통해 저항을 계속하고, 유엔군 의 진격을 지연시킨다는 방어 계획을 세웠었다(On, 2001, p. 792). 김일성과 박헌영은 금천이 탈취 된 10월 14일, r조선인민군 최고사령관 명령 0070호」를 하달하고선 평양을 탈출하였다. 주된 내용 은 일보도 퇴각하지 말고, 마지막 피 한 방울까지 다하여 진지를 사수하라는 것이었다(Park, 2009, p. 503-509). 따라서 북괴군이 평양 이남으로 3중의 방어선을 형성한 것의 주된 목적은 바로 시간을 벌기 위한 것이었으며, 금천점령 간 미 제8기병연대와 제5기병연대의 더딘 진격속도는 결과적으로 북괴군이 시간을 벌 수 있도록 해 주었음을 알 수 있다.3)

\section{2단계 사리원 진격 : 미 제24사단의 유휴 병력화}

\section{1 미 제 1 기병사단과 제 24 사단의 사리원 입성 경쟁}

북괴군의 방어진지 중 제 1 선이 돌파되자, 미 제 1 군단장 밀번 소장은 군단 예비인 미 제 24 사단을 개성 서측방으로 진격시켜 미 제 1 기병사단의 좌측방을 엄호하면서 북진하도록 하는 등 군단 예하 3 개 사단을 모두 북진작전에 투입하였다. 군단 중앙의 미 제 1 기병사단은 선두의 미 제 7 기병연대가 남천점에서 서흥 방면으로 진격하고, 군단 우익인 국군 제 1 사단은 신계를 거쳐 수안으로 진격하는 임무가 부여되었다. 나머지 2개 연대와 영연방 제 27 여단은 남천점-금천 선에서 그 뒤를 후속하도

3 ) 미 제 7 기병연대 3 대대가 10 월 12 일 노획한 북괴군 지도에는 금천 부근에서 방어하고 있던 북괴군 제 19 사단과 제 27 사단이 10 월 14 일 밤에 남천점으로 철수할 계획이 적혀 있었다. 이를 통해 북괴군의 주된 방어 목적이 유엔군 진격 지연에 있었음(Institute for Military History, 1986, p. 78; War Commemoration Service Society, 1992, p. 280). 
록 계획되었다(Institute for Military History, 1986, p. 101). 미 제1기병사단장 게이 소장은 위와 같 은 군단계획에 따라 38 도선-평양 축선 상의 요충지인 사리원을 점령하기 위하여 아래와 같은 기동 계획을 수립하였다(Institute for Military History, 1986, p. 102).

(1) 공격 개시일은 10 월 15 일 07:00로 하며, 사단의 최선봉부대로서 남천점-서흥 축선으로 진격 중인 미 제 7 기병연대가 서흥을 점령하면, 그 뒤를 후속 중인 영연방 제 27 여단이 연대를 초월 하여 사리원을 정면에서 공격한다.

(2) 미 제7기병연대는 서흥으로부터 신당리로 우회기동하여 사리원 북방 $18 \mathrm{~km}$ 황주로 진출하여 적의 퇴로를 차단하고, 일부 병력을 남진시켜 사리원을 북쪽에서 공격한다.

(3) 미 제5기병연대는 서쪽으로 우회하여 남천점-청석두리-신원-재령-사리원 선으로 공격한다.

10 월 15 일 07 시, 미 제 7 기병연대는 1 대대를 선두로 사리원 방면 공격을 개시하였다. 하지만 북괴 군은 계속된 패전에도 불구하고, 여전히 강력하고 조직적인 저항을 지속적으로 전개하였다. 그리고 이날 오후부터 내리기 시작한 비로 인해 미 제 5 기병연대의 기동계획에 차질이 생기기까지 하였다. 결국, 미 제 1 기병사단의 진격작전은 당초 계획보다 전반적으로 지연되기 시작하였다(Institute for Military History, 1986, p. 103). 아래 Figure 2를 보면, 10월 15일을 기점으로 국군 제1사단의 진출 부대 위치보다 미 제 1 기병사단의 진출 부대 위치가 현저하게 뒤처져 있음을 알 수 있다.

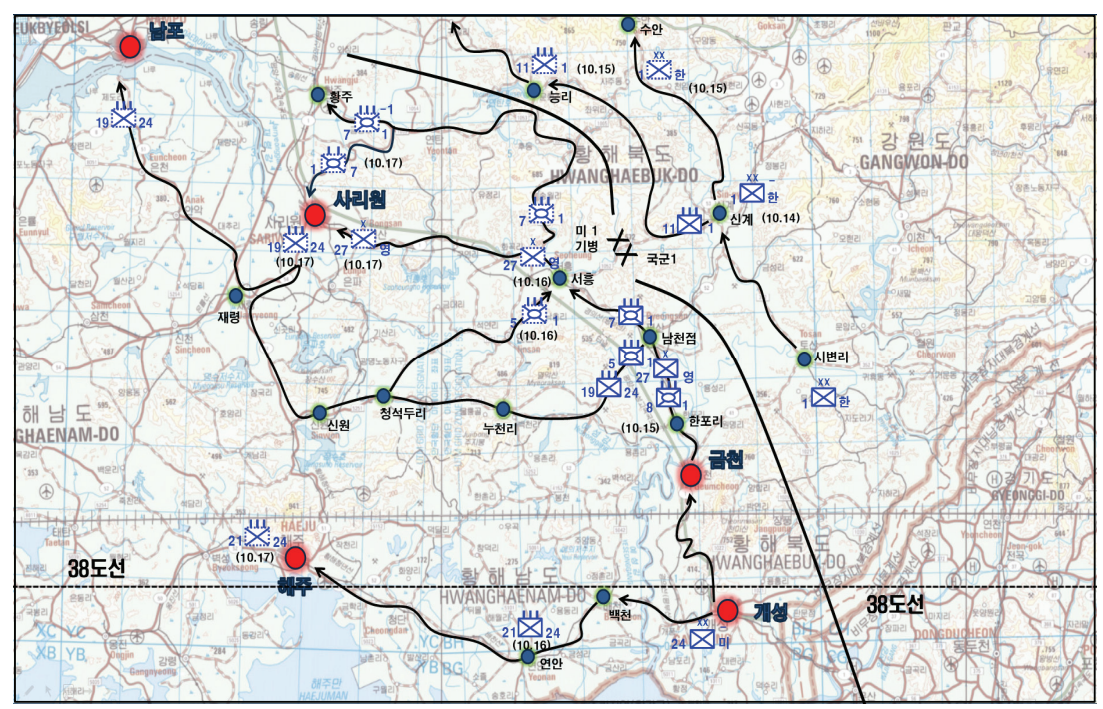

<Figure 2> The U.N. Forces' Advance to Sariwon

금천점령 시부터 워커 장군으로부터 진격이 너무 늦다는 지적을 받고 있던 미 제 1 군단장 밀번 
소장은 미 제 24 사단장 처치(John H. Church) 소장에게 미 제 1 기병사단의 좌측방을 엄호하면서 사 리원을 점령하고, 평양을 향하여 계속 진격하라는 명령을 하달하였다. 미 제 1 기병사단장 게이 소장 도 영연방 제 27 여단으로 하여금 미 제 7 기병연대의 직후방을 후속하다가 서흥에서 연대를 초월하여 사리원을 점령하라는 명령을 하달하였다(Institute for Military History, 1986, p. 103-104; On, 2001, p. 795-796). 10월 16일 금천-남천점 국도는 미 제7기병연대에 이어 서흥에서 미 제7기병연대 를 초월공격 하기 위하여 북진 중인 영연방 제 27 여단과 그 뒤를 후속한 미 제5기병연대, 미 제 24 사 단 제 19 연대의 차량대열로 대혼잡을 이루었다. 이 와중에도 각 부대 장병들 간에는 군단장인 밀번 소장이 게이 소장과 처치 소장에게 '먼저 사리원을 점령하는 사단에게 평양에 먼저 입성할 수 있는 영광을 줄 것'이라는 약속을 하였다는 소문이 퍼졌다(Institute for Military History, 1986, p. 105; On, 2001, p. 796). 이처럼 미 제1군단 예하 모든 부대는 적의 수도인 평양을 서로 먼저 탈환하려는 경쟁심에 불타기 시작하였다. 평양을 향한 과도한 경쟁으로 인해 10 월 17 일 새벽에는 서흥 남쪽에 서 미군끼리 사격전을 벌이는 불상사가 일어나기도 하였다. 10 월 16 일 서흥에 진출한 미 제 7 기병연 대는 예하 제3대대 F중대(중대장 : Arthur H. Truxes 대위)에게 일출 전까지 차단 진지 전방에서 움직이는 모든 물체에 대하여 즉각 사격을 가하라고 명령하였다. 이러한 가운데 미 제 5 기병연대 제 1 대대의 선두가 10 월 17일 새벽 03:00를 기해 아무런 사전 협조도 없이 서흥 남쪽 $1.5 \mathrm{~km}$ 지점의 미 제7기병연대 전초진지로 진격해 옴으로써 서로 적으로 오인한 양개 연대 사이에 교전이 전개되 었다. 이 교전은 잠시 후 서로 우군임이 밝혀져 중지되었으나, 이와 같은 불상사로 미 제5기병연대 병사 7명이 부상하였다(Institute for Military History, 1986, p. 105-106).

유엔군 부대들 간 과도한 경쟁으로 인해 사리원 점령 간에도 문제가 발생하였다. 10월 17일 저녁 무렵, 사리원에 진입한 영연방 제 27 여단의 호주군 대대는 사리원을 그대로 점령하고 있는 북괴군을 한국군 카투사로 오인하여 그냥 지나치기도 하였다. 북괴군 역시 호주군을 소련군 고문단으로 간주 하여 ‘동무’라고 부르면서 담배를 나누어 피우기까지 하였다(Kim, 1986, p. 19-20; On, 2001, p. 796). 이처럼 유엔군은 평양탈환을 눈앞에 두고, 서로 과도하게 경쟁한 나머지 숙련되지 못한 모습을 보 였다. 유엔군의 이러한 모습을 통해 평양을 향한 북진 작전에서 군단 내 사단 간 경쟁뿐만 아니라 사단 내 예하 부대 간에도 서로 경쟁 관계에 있었음을 알 수 있다.4) 비록 이러한 과오들은 유엔군 에 큰 피해를 야기하지 않았으나, 필요한 절차가 생략되거나 확인되어야 할 것들이 제대로 확인되 지 않았기 때문에 과오로 인정할 만한 단서라고 볼 수 있다.

4) 당시 미군들 사이에서 “평양만 탈환하면 일본으로 돌아간다.”라는 루머가 나돌았으며, 미군들은 빨리 돌아가기 위해 평양진격을 서둘렀는지도 모른다. 그러나 이는 “평양만은 반드시 우리가 점령해야 한다."는 결의에 찬 국군의 의지와는 대비된다고 볼 수 있다. (On, 2001, p. 797). 


\section{2 미 제 24 사단의 평양탈환 전투 배제}

10 월 17 일, 미 제 1 기병사단은 강력한 적의 저항을 물리치고 사리원을 제일 먼저 점령하게 되었으 며, 군단장이 약속한 대로 군단의 맨 선두에서 평양을 공격하게 되었다. 같은 날 미 제 24 사단의 제 21 연대가 해주를 점령하였으며, 제 19 연대는 청석두리-신원리-재령을 거쳐 사리원 약 $10 \mathrm{~km}$ 근방까 지 진격하였으나, 사리원이 미 제 1 기병사단에 의해 점령된 이후였으므로 군단장은 미 제 24 사단의 사리원 진격을 중지시켰다(On, 2001, p. 796-797). Figure 2에서 알 수 있듯이 미 제24사단은 이튿 날 진격 방향을 남포 방향으로 전환하여 진격하게 됨으로써 평양 공격 대열에서 이탈하게 되었다. 이후 평양탈환 전투에서 미 제 24 사단에 대한 언급은 나타나지 않았다. 미 제 24 사단에 대한 기록은 평양탈환 이후인 10 월 20일, 숙천 방면으로의 진격작전에서 등장한다. 평양을 탈환하기까지 더 이 상 미 제 24 사단에 대한 언급이 나타나지 않는 것으로 보아 평양탈환 전투에서 미 제 24 사단은 완전 히 배제되었다고 보는 것이 타당할 것이다(On, 2001, p. 796-797).

\section{3 분석 및 평가}

금천 점령 이후 평양진격 간 발생한 유엔군의 전술적 과오는 크게 두 가지로 볼 수 있다. 첫 번째 는 평양진격에 대한 유엔군의 과도한 경쟁으로 인해 전술적 과오를 낳았다는 것이다. 이는 세 가지 사례를 통해 입증될 수 있다. 먼저, 유엔군은 평양진격 간 상호 협조 된 공격을 통해 효과적인 전투 를 수행하기보다는 경쟁심에 불타 서로의 작전지역까지도 무단으로 침범하는 어처구니없는 실수 를 저지르고 있었다. 이는 10 월 13 일 금천 진격 간 미 제 5 기병연대가 북우리 일대에서 금천 방향으 로 서진하기 이전에 국군 제 1 사단의 책임 지역을 침범한 뒤에 발생한 두 번째 침범사례였다. 둘째, 제한된 기동로에 많은 부대가 동시에 밀집되면서, 도로사용에 대한 통제가 제대로 이루어지지 않아 자칫 큰 피해를 가져올 수도 있었다. 금천-남천점 간 도로상에 전차 1 개 대대를 배속받은 미 제 1 기 병사단의 모든 부대와 이를 후속하던 미 제 24 사단 제 19 연대가 동시에 몰리는 바람에 큰 혼잡을 빚 게 된 것이다. 셋째, 유엔군은 목표지역 점령 시, 피·아 구분조차도 제대로 하지 않고 적과 근접하 여 아찔한 상황을 초래하였다. 이처럼 평양 입성에 대한 과도한 경쟁으로 인해 유엔군은 진격 도중 숙련되지 못한 모습을 종종 드러내었다.

두 번째 과오는 평양탈환 전투에서 미 제 24 사단을 배제시킴으로써 전투력 집중에 실패했다는 것 이다. 미 제 24 사단 운영에 관한 밀번 소장의 최초 계획은 북진 간 미 제 1 기병사단의 좌측을 엄호하 되, 군단의 예비사단으로서 언제든지 미 제 1 기병사단을 초월할 수 있도록 준비하는 것이었다(On, 2001, p. 794). 또한, 맥아더라인까지 북진하기 위해 북괴군이 패잔병을 수습하고, 예비부대를 투입 하여 축차 방어진지를 구축하기 전에 신속하게 진격하는 것이 무엇보다 중요하다고 판단하였다. 특 히 밀번 소장은 주공사단이 지향하게 될 개성-평양 축선으로 우세한 화력과 기동력을 갖춘 미군 
2개 사단을 교대로 투입하여 공격 기세를 유지하기로 하였다(Institute for Military History, 1986, p. 61). 따라서 사리원 진격 이후 미 제 24 사단을 평양 탈환 작전에서 배제시킨 것은 미 제 1 군단의 최초 계획을 번복하는 것이었다. 평양탈환 작전 간 미 제 24 사단이 임무에서 배제되었다는 것이 현 재까지 이루어진 연구의 결과이다. 당시 미 제 24 사단을 남포 방면으로 진격시킴으로써 얻을 수 있 었던 이익이 무엇이었는지 밝혀진다면, 미 제 24 사단의 평양탈환 임무 배제에 대한 평가는 새로운 관점에서 재해석될 여지가 충분하다. 그러나 평양탈환 자체가 갖는 전략적 이익에 비추어볼 때, 이 보다 더 중요한 이익이 있어 보이지는 않는다. 따라서 현재까지 이루어진 연구결과를 토대로, 평양 탈환 전투에서 미 제 24 사단을 배제한 것은 분명한 한계로 여겨질 만한 단서라고 할 수 있다.

\section{3단계 평양 점령 : 국군 제 1 사단의 신속한 진출과 적 퇴로 방치}

\section{1 최초의 보·전·포 협동 공격}

국군 제 1 사단은 군단으로부터 고랑포 이남의 38 도선을 돌파한 이후 군단의 우측방을 엄호하면서 시변리와 신계, 율리, 평양 축선으로 진격하라는 임무를 부여받고 10 월 10 일 저녁 고랑포 일대 집결 을 완료하였다. 이는 미 제 1 기병사단의 38 도선 돌파일인 10 월 9 일보다 이미 하루가 늦은 것이었다. 국군 제 1 사단은 38 도선 일대에 대한 북괴군의 방어상황을 정찰한 이후 북진 작전을 개시하여 10 월 11일 38도선을 돌파하였다(Institute for Military History, 1986, p. 86-88; On, 2001, p. 793-794; War Commemoration Service Society, 1992, p. 284).

국군 제 1 사단의 첫 번째 공격 목표는 금천보다 두 배가 더 먼 시변리였다. 사단장 백선엽(白善 燁) 준장은 우측의 제 15 연대로 하여금 고랑포에서 동북방 마전리를 거쳐 임진강을 따라 삭령-토산시변리 축선으로 원거리를 우회 기동하도록 하였다. 좌측의 제 11 연대는 고랑포 좌측방의 춘양리에 서 거의 직선으로 북방의 구화리를 거쳐 위천리-황계치-시변리로 진격하도록 하였다. 예비인 제12 연대는 사미천 계곡을 따라 제11연대를 후속하도록 계획하였다(Institute for Military History, 1986, p. 86-87). 하지만 미군에 비해 기동로가 협소하고 장비가 열악하여 국군 제 1 사단은 미군만큼 진격속도를 발휘할 수가 없었다. 38 도선을 통과한 10 월 11 일 하루 간 국군 제 1 사단의 진격 거리는 우측의 제 15 연대가 $2.5 \mathrm{~km}$, 좌측의 제 11 연대가 $4 \mathrm{~km}$ 에 불과하였다. 이에 사단장 백선엽 준장은 느린 진격속도로 인해 미 제 1 군단장에게 약속한 평양 선봉 입성이 어렵게 되지 않을까 하고 우려하지 않을 수 없었다(Institute for Military History, 1986, p. 89-90).

다부동 전투 때부터 사단을 지원해 온 미 제10고사포단장 헤닝(Henning) 대령은 백선엽 사단장 에게 '보·전·포 협동 돌파작전'을 건의하였다. 즉, 적의 저항을 야포와 항공기로 제압하면서 보병 의 엄호를 받는 전차로써 적의 진지를 돌파하면, 그 뒤를 주력부대가 차량 기동으로 후속하는 작전 
이었다. 그렇게 하면 사단의 진격속도가 훨씬 빨라질 것이라 주장하였다(Institute for Military History, 1986, p. 90-91). 사단장은 이를 받아들여, 예비 연대인 제12연대가 제6전차대대 C중대와 미 제 10 고사포단, 그리고 국군 제 17 포병대대 $\mathrm{C}$ 포대와 보 - 전 - 포 협동작전을 전개하도록 하였다. 보·전 - 포 협동작전으로 인해 진격속도에 탄력을 받은 국군 제 1 사단은 여세를 몰아 북진을 계속 하였다. 그 결과, 미 제 1 기병사단에 비해 38도선을 사흘이나 늦게 돌파했음에도 불구하고 10 월 12 일에는 토산까지 진출함으로써 미 제 1 기병사단과 함께 금천과 시변리를 포위 공격할 준비를 완료 하게 되었다(Institute for Military History, 1986, p. 92-94).

10 월 13 일 토산을 통과하여 시변리로 진출을 시작한 국군 제 1 사단은 적이 매설한 지뢰지대를 개 척하는데 일부 시간을 지체하였을 뿐, 큰 저항 없이 시변리로 향하였다. 이날 제 12 연대는 보 - 전 포 협동작전으로 주간에만 약 $25 \mathrm{~km}$ 를 주파함으로써 오후 일찍 시변리에 도착할 수 있었다. 이로써 국군 제 1 사단은 주요 도로가 교차하는 교통의 요충지인 시변리를 점령하고, 적의 퇴로를 차단하는 데 성공하였다(Institute for Military History, 1986, p. 95-98). 그 결과, 우대각선 모양의 일자별 진 출선처럼 국군 제 1 사단은 미군보다 앞서 평양을 향해 진출할 수 있었다(Figure 3 ).

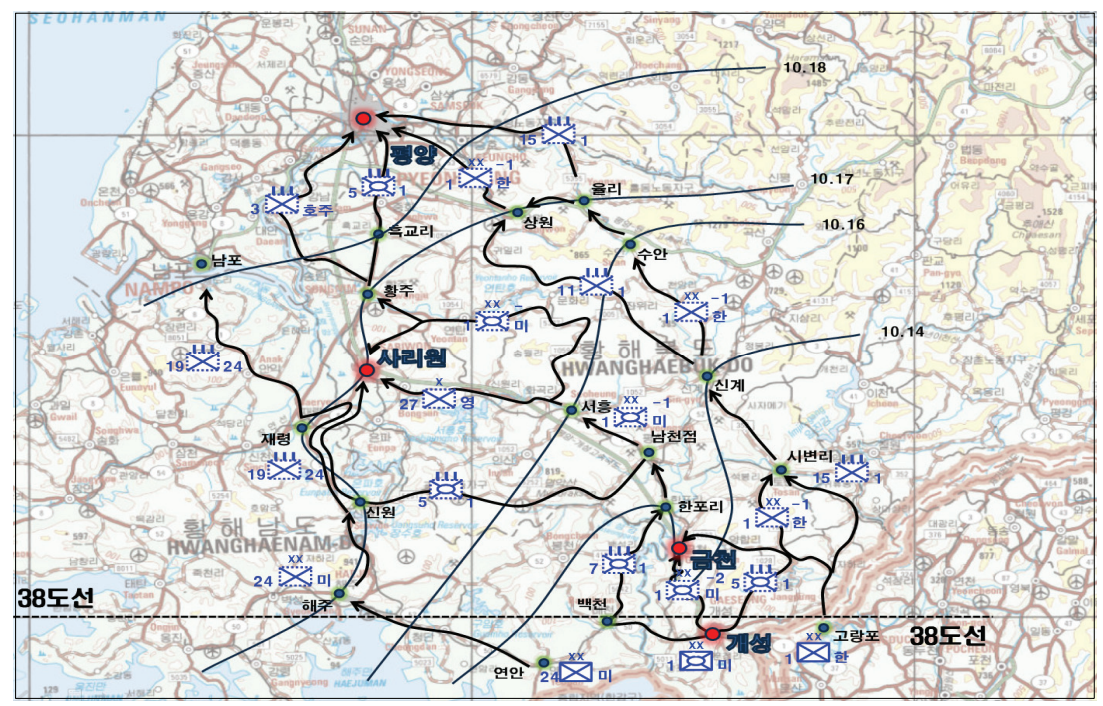

$<$ Figure 3> The U.N. Forces' Advance to Pyongyang

평양을 향한 국군 제 1 사단의 진격은 비교적 순조로운 가운데 진행되었으며, 상원-율리 진격 간 에는 사단 우익의 제 12 연대가 하루에 약 $30 \mathrm{~km}$ 를, 사단 좌익의 제 11 연대는 약 $21 \mathrm{~km}$ 를 진격하는 위 용을 보여주었다. 특히 10 월 17 일, 율리를 향한 진격에서는 일일 직선거리로서 최고 기록인 $42 \mathrm{~km}$ 를 진격함으로써 평양 점령을 목전에 두게 되었다(Institute for Military History, 1986, p. 119). 국군 제 1 사단은 열세한 기동력에도 불구하고 10 월 16 일부터는 서흥까지 진출한 미 제 1 기병사단을 약 
$12 \mathrm{~km}$ 정도 앞지르고 있었다(Institute for Military History, 1986, p. 116-119). 이처럼 국군 제1사단 이 보여준 보·전·포 협동 공격과 장병들의 전의, 용맹이 모든 난관을 극복하고 작전을 성공시킬 수 있는 요체가 되었다고 평가되고 있다(War Commemoration Service Society, 1992, p. 299).

\section{2 북한군의 후퇴 및 패주}

국군 제 1 사단이 진격 간 마주한 북괴군의 저항은 주공인 미 제 1 기병사단에 비해 상대적으로 빈 약하였다. 국군 제 1 사단의 책임지역인 고랑포 북방 지역에는 북괴군의 신편 사단인 제 17 기갑사단 이 담당하여 방어하고 있었다. 평양탈환 작전 후반 무렵, 미 제 1 군단 정보참모부가 내린 정보 판단 에 의하면, 고랑포 북방지역을 방어하던 이 부대는 계속 국군 제 1 사단과 접촉을 유지하면서 평양으 로 철수한 후 신편 부대인 북괴군 제 32 사단과 함께 평양 방어를 시도했던 것으로 알려졌다. 하지만, 실전경험이 없는 신병들로 편성되었기 때문에 공군력을 비롯한 유엔군과는 비교가 안 될 정도로 열세인 데다가, 후방으로부터의 보급지원마저 차단당하고 있었다(Institute for Military History, 1986, p. 67).

국군 제 1 사단의 평양진격 간 기록(전투상보)을 살펴보면, 국군이 북괴군의 상황에 대해 어떻게 평가했는지 알 수 있다. 당시 북괴군은 “고급장교의 살상, 포로 및 투항자 속출 등으로 내 - 외부적 으로 조직이 분열되고, 전투의식이 희박하다.”고 기록되어 있다. 또한 “아군의 맹공(猛攻)에 분쇄되 어 평양을 목표로 계속 후퇴하고, 일부가 간간히 저항 중”이거나, “사기가 극도로 저하되어 도처에 서 도피 혹은 포로로 되는 자가 많고, 심지어 자살한 자도 심심치 않게 목격”되고 있었다(ROK Army Military History Institute, 2020). 물론, 일부 국면에서 북괴군은 유격대 활동 등을 통한 저항 을 시도하기도 하였지만, 부대의 진출 속도를 수일 간 지연시킬 정도의 강력한 저항은 없었다고 볼 수 있다.

국군 제 11 연대는 진출 간에 적으로부터 노획한 문서를 통해 연대 진격로 상에 표시된 지뢰지대 와 화기배치를 사전에 알게 되었다. 따라서 연대는 적의 화기 배치도에 표시된 화기 진지를 차례로 공격 및 점령하면서 조심스럽게 전진하였다. 그러나 막상 적의 화기 진지를 점령하고 보면, 거기에 는 실전 경험이 전무한 신병들이 잇단 패전으로 사기마저 극도로 저하된 상태로 방치되어 있었다. 혹은 국군이 미처 공격하기도 전에 새로 지급받은 화기마저 유기하고 도주 또는 후퇴해 버린 흔적 이 역력하였다(Institute for Military History, 1986, p. 89-90). 이후 국군 제1사단은 큰 저항 없이 신계 점령까지 완료하게 되고, 신계-도아리-능리 축선으로 진격할 때에는 적의 저항 없이 약 $21 \mathrm{~km}$ 를 그대로 진격한 경우도 있었다. 이리하여 10 월 16 일에는 국군 제 1 사단이 열세한 기동력에도 불구 하고 평양 남동쪽 $64 \mathrm{~km}$ 지점인 수안-능리 선까지 진출함으로써 평양 남쪽 $72 \mathrm{~km}$ 지점 서흥까지 진출한 미 제 1 기병사단을 앞지르게 되었다. 국군 제 1 사단은 율리-상원 진격 간에도 적의 간헐적인 저항에 직면하였을 뿐, 거센 저항에 부딪히지 않고 무난한 진격을 계속하였다. 국군 제 1 사단은 진 
격 간 퇴각 중인 연대 규모의 북괴군을 식별하기도 하는 등 거센 저항에 부딪힌 미 제 1 기병사단보 다 훨씬 유리한 여건 속에서 평양을 향해 진격할 수 있었다. 결국, 국군 제 1 사단은 10 월 17 일, 38 도 선 돌파 이후 일일 진격 거리로서 최고 기록인 $42 \mathrm{~km}$ 를 진격함으로써 평양 점령을 약 20 여 $\mathrm{km}$ 앞두 게 되었다(Institute for Military History, 1986, p. 116-120).

\section{3 평양 선봉 입성에 대한 집착}

평양탈환을 위한 미 제 1 군단의 최초 작전계획은 국군 제 1 사단이 군단의 좌측방을 엄호하며 남포 방향으로 진출하는 것이었고, 미 제 24 사단이 군단의 우측방을 엄호하며 시변리-율리-상원 일대로 진출하는 조공 임무를 수행하는 것이었다. 하지만 평양 태생인 국군 제 1 사단장 백선엽 준장은 평양 탈환만큼은 국군이 해야 한다면서 군단장인 밀번 소장에게 간청하여 결국 임무를 조정받게 되었다. 미군보다 앞서 평양에 입성해야 한다는 집착은 이승만 대통령도 예외는 아니었다. 그는 미 제 10 군 단에 앞서 국군 제 1 군단이 원산을 점령한 것에 고무되어 평양 입성 역시 국군이 먼저 해야 한다는 지시를 육군 총참모장에게 하달하였다. 이에 따라 미 제 1 군단 외에도 국군 제 2 군단과 제 7 사단 8 연 대도 평양탈환 작전에 참여하는 등 매우 복잡한 양상을 띠게 되었다. 결국, 국군 제 1 사단은 미군보 다 먼저 평양에 입성하였다. 그리고 미 제 1 기병사단과 함께 각각 본평양과 동평양을 분할하여 점령 하였다. 하지만 앞서 언급하였듯이 모든 부대들이 평양으로 입성하는 데만 급급하였을 뿐, 평양 북 방에 대한 퇴로를 차단하려 하거나, 이후 작전에 대비하려는 모습은 찾아볼 수 없었다.

평양 선봉 입성에 대한 집착은 국군 제 1 사단의 예하 부대들 사이에서도 찾아볼 수 있다. 본격적 인 평양탈환 작전이 진행되던 10월 19일부터 20일까지 제 15 연대 예하 부대들은 지형을 제대로 살 피지 못한 상태에서 엉뚱한 방향으로 부대를 이동시키는가 하면, 서로의 작전지역을 침범하기도 하 였다. 또한, 예비임무를 부여받은 대대가 지나친 경쟁심에 불탄 나머지, 일선 대대와 함께 공격에 나서는 모습도 보였다. 본평양 중심의 내각본부 점령 시에는 태극기 게양문제로 같은 부대끼리 시 비가 벌어지기도 하였다. 하지만 연대 지휘부는 예하 부대들과의 연락이 두절되어 효과적인 통제를 하기도 어려운 상황이었다(Institute for Military History, 1986, p. 149-159).

\section{4 분석 및 평가}

국군 제 1 사단은 최초의 보 - 전 - 포 협동 공격을 통해 미군보다 열세한 장비와 기동력에도 불구 하고, 10 월 16 일부터는 미군을 앞지르기 시작하였다. 이는 북괴군의 수도를 탈환하겠다는 강한 집 념과, '휴식없는 진격'을 통해 이루어낸 쾌거로 평가받고 있다. 물론 보·전·포 협동 공격을 통해 국군 1 사단이 진격에 속도를 낼 수 있었던 것은 부인할 수 없는 사실이다. 하지만, 이와 더불어 국 군 제 1 사단이 마주한 적의 저항 역시 미 제 1 기병사단에 비해 크지 않았다는 사실을 간과해서는 안 
된다.

적 배치를 살펴보면, 미 제 24 사단이 기동하게 될 좌측지역은 북괴군 제 43 사단이, 미 제 1 기병사단 이 기동하게 될 개성-금천 가도는 북괴군 제 19 사단과 제 27 사단이, 그리고 국군 제 1 사단이 기동하 게 될 우측지역은 북괴군 제 17 사단이 배치되어 있었다. 즉, 주공인 미 제 1 기병사단이 금천 진격에 약 5 일을 소모할 만큼의 강력한 저항이 국군 제 1 사단 앞에는 없었다. 물론 국군 제 1 사단이 평양에 선봉으로 입성할 수 있었던 주요한 요인은 불굴의 투지와 집념, 그리고 최초의 보·전 - 포 협동작 전을 통한 공격 기세 유지 노력을 부정할 수는 없으나, 무엇보다 적의 저항이 그리 강하지 않았다 는 것도 매우 주요한 요인 중 하나로 여겨질 수 있다. 전반적인 상황을 고려해 볼 때, 국군 제 1 사단 이 평양 선봉 입성에 대한 집착을 버리고 우세한 진격속도를 바탕으로 평양 후방에 대한 퇴로를 차단할 수 있었더라면 하는 아쉬움이 남는다. 당시 평양 선봉 입성에 대한 부대별 경쟁이 매우 치 열했음을 나타내는 단서들이 다양하게 존재한다. 이승만 대통령은 평양 선봉 입성은 반드시 국군이 해야 한다며 정일권 총참모장에게 특별지시까지 내렸다. 이에 따라 중부 전선의 7사단 8연대가 서 진하여 평양으로 진출하였다. 이렇듯 국군과 유엔군 사이에서의 경쟁이 있었고, 국군은 국군대로, 유엔군은 유엔군대로 각자 내부적으로도 경쟁심에 불타있었다. 미 제 1 군단은 국군 제 1 사단 축선에 서 적의 저항이 크지 않았다는 유리한 상황, 그리고 최초의 보·전·포 협동 공격이라는 획기적인 계획을 효과적으로 활용하지 못하였다. 미 제 1 군단은 평양 진격 작전에 있어, 퇴로 차단과 양익 포 위의 전술을 주요한 전술 개념으로 삼았다. 하지만, 정작 평양으로의 최종 진격에 있어서 너나 할 것 없이 모든 부대가 평양으로 진격함으로써 혼선을 빚게 되었고, 퇴로 차단을 위한 노력은 부재하 게 되었다. 만약 군단에서 가장 빠른 진격속도를 보였던 국군 1 사단이 평양으로 들어갈 것이 아니 라, 평양 북방인 숙천과 순천 방면의 퇴로를 차단하는데 운용되었더라면 하는 아쉬움이 남는다.

결과론적으로 이미 북한의 전쟁지도부와 주력이 평양을 빠져나간 뒤였다고는 하지만, 당시 상황 으로서 유엔군은 이를 전혀 알 수 없었다. 따라서 미 제1군단의 평양 이북에 대한 퇴로 차단 노력은 필수였다고 보는 것이 타당하다. 모든 부대가 평양 선봉 입성에 대한 경쟁심에 불탄 나머지 여러 혼잡한 상황을 연출해가면서까지 평양으로 일거에 진격할 수밖에 없었던 전술적 과오는 부대 간 경쟁심을 조장하고, 평양 후방에 대한 세부적 계획을 마련하지 못했던 미 제 1 군단장의 작전지도에 그 원인이 있음을 인정하지 않을 수 없다.

\section{$\mathrm{V}$. 결론 및 논의}

앞서 다양한 근거들을 통해 평양탈환 전투가 갖는 한계에 대해 고찰해 보았다. 우선적으로 유엔 군은 북괴군이 부대를 재편하기 이전에 추격과 전과확대를 위해 신속한 진격이 필요하였다. 하지 만, 금천 진격에 5 일을 소모하게 되면서 결과론적으로 북한 전쟁지도부 및 주력 부대의 철수를 허 
용하고 말았다. 둘째, 미 제 1 군단은 평양진격 간에 한 개 사단을 배제하여 평양탈환 작전에 대한 전투력 집중 및 공격 기세를 유지하는 데 실패하였다. 마지막으로 평양탈환 전투에 대한 과도한 경 쟁심으로 인해 정작 최종단계에서는 퇴로를 차단하려는 노력에 실패하였다. 그리고 국군 제 1 사단 이 열세한 기동력에도 불구하고 평양에 선봉으로 입성했다는 거대한 성과의 이면에는 북괴군의 배 비 자체가 그리 강하지 않았다는 사실에 대한 재평가의 여지가 남아있다.

유엔군이 마주한 북괴군의 대부분은 시간을 벌기 위한 지연전을 펼치고 있었다고 볼 수 있다. 추 후에 출판된 북간의 공간사(公刊史)인 『전쟁사』의 제 3 장 제 2 절 “전략적 철수”에서 북괴군은 유엔 군과 한국군의 진격속도를 늦추게 하여 유엔군의 포위망 속에 갇힌 인민군 주력부대를 철수시키는 것이 목표였다고 기록하고 있다(War Commemoration Service Society, 1992, p. 291). 이는 적이 작 전의도와 목표를 달성하도록 허용했다는 측면에서, 진격 작전 초기 금천에서 적의 지뢰를 일일이 제거하느라 시간을 과도하게 지체한 미 제 1 기병사단의 과오는 분명 재평가해볼 가치가 있는 문제 이다. 평양 북방에 대한 퇴로 차단 노력의 부재는 특히 아쉬움이 남는다. 평양 북방에 대한 퇴로 차단으로 북한의 전쟁지도부를 사로잡으려는 구상은 이미 평양탈환 이전부터 존재하였다. 유엔군 은 이미 적이 평양사수 작전을 펼치는 경우에 대비하여 공수작전을 구상하였다. 미 제8군사령부 정 보처는 “북한군이 청천강 이북으로 철수하여 차기 작전을 시도한다면, 평양을 사수함으로써 시간 을 벌려고 할지 모른다"고 보고했다. 맥아더 사령관은 미 제8군의 정보보고를 토대로, 공수부대를 통해 평양후방의 퇴로를 차단함으로써 북한 정부 수뇌들을 사로잡아 수천 명의 유엔군 포로를 되 돌려 받을지 모른다고 생각하였다. 따라서 그는 제 187 공정여단으로 하여금 언제든지 작전에 투입 할 수 있도록 준비하라고 명령하였다(On, 2001, p. 809-810). 결국, 평양 북방에 대한 퇴로 차단 구 상은 새로운 것이 아니라, 유엔군이 이미 구상하고 있던 작전 개념이었다. 그러나 미 제 1 군단 예하 부대들은 평양 탈환에만 급급하였고, 평양 이북에 대한 퇴로를 그대로 방치하였다. 이러한 과오들 은 결국 예하 부대들의 경쟁을 조장하고, 평양 이북에 대한 구체적 계획을 마련하지 않은 미 제 1 군 단장의 작전지도에 근본적인 원인이 있다고 할 수 있다. 즉, 상급부대의 작전 목적 달성에 기여하지 못했다는 측면에서 과오로 여길 수 있는 문제이다.

평양탈환 전투는 그동안 여러 연구에 의해 분석되고, 평가되어왔다(Jung, 2007; Kim, 1986; Nam, 2001; On, 2001, 2010; Park, 2009). 기존 연구들에 의하면 평양탈환 전투는 매우 성공적인 작전이며, 유엔군이 한만(韓滿) 국경까지 진격하게 된 발판이 되었다. 그리고 장비의 열세에도 불구하고 국군 제 1 사단이 불굴의 의지와 집념, 투지로 적의 심장부인 평양에 선봉으로 입성하게 된 매우 자랑스러 운 전투로 기억되고 있다. 이처럼 평양탈환 전투는 충분히 긍정적으로 평가받을 만한 전투였음은 분명하다. 하지만, 평양으로의 진격 과정에서 유엔군이 보여준 여러 과오들은 평양탈환 전투를 재 평가할 만한 유의미한 단서를 제공한다. 지금까지 이러한 과오가 커다란 실패로 이어지지 않았기 때문에 주목받지 못하였으나, 이들은 분명 큰 피해를 야기하거나 전투가 더 나은 양상으로 전개되 는 것을 방해한 전술적 과오였음은 분명하다. 이런 의미에서 본 연구는 역사적인 고찰을 토대로 평 
양탈환이라는 성과 자체에 고무되어 정확하게 평가되지 못한 전술적 과오를 재분석하여 미래에 대 비할 수 있는 교훈을 제시하였다는 데 학술적 시사점이 있다. 후속연구는 개별 전투를 단순히 그 자체만으로 개별 전투의 성 - 패 여부를 평가하는 접근이 아니라 관련 전투 및 상위의 작전적 수준 과의 연계분석을 통해 재평가하는 노력이 필요하다.

\section{Acknowledgements}

We would like to thank Editage (www.editage.co.kr) for English language editing.

\section{Declaration of Conflicting Interests}

The author(s) declared no potential conflicts of interest with respect to the research, authorship, and/or publication of this article. 


\section{Reference}

Institute for Military History. (1986). The History of Korean Warfare : Battle of Pyeongyang, Seoul: Department of Defense.

Institute for Military History. (2009). The History of Korean War, Seoul : Department of Defense.

Institute for Military History. (2017). The Main Battle of Korean War, Seoul: Department of Defense.

Jang, H. (2001). The Combat Order of North Korean Army in Korean War, Seoul: Department of Defense.

Jung, I. (2007). MacArthur's Korean War different from what we know, Gyung-gi: Future Korea.

Kim, J. (1986). A Strategic Study on the Pyongyang Recapture Operation, Military History, 13, 7-26. UCI : G901:A-0000637063

Nam, J. (2001). A Study on the Top 10 Battle of the Korean War, History of War, 3, 138. UCI : G901:A-0001504813

On, C. (2001). The History of Korean War, Seoul : Jipmoondang.

On, C. (2010). 60 Battles of Korean War, Seoul : Goldegg Inc.

Park, M. (2009). Korea 1950: War and Peace, Gyung-gi : Nanam Publishing House.

ROKArmy Military History Institute. (2013). Cases and Lessons of Failure in the Korean War, Chung-nam: ROKArmy Military History Institute.

ROKArmy Military History Institute. (2017). History of Korean War, Chung-nam: ROKArmy Military History Institute.

ROKArmy Military History Institute. (2020). Combat Detail Report(ROK $1^{\text {st }}$ Division $11^{\text {th }}$ Regiment), Chung-nam: ROKArmy Military History Institute.

War Commemoration Service Society. (1992). The History of Korean War, Seoul: War Commemoration Service Society. 
국문초록

https://doi.org/10.37944/jams.v4i1.97

\title{
$6 \cdot 25$ 전쟁 평양탈환 전투에 대한 전술적 과오(過誤) 분석
}

\author{
박지수*
}

본 연구는 6 - 25 전쟁 시 미 제 1 군단의 평양탈환 전투를 전투사(戰㴻史)적으로 고찰한다. 유엔군의 평양탈 환 전투는 북한의 심장인 평양을 점령함으로써 얻을 수 있는 이점을 최대한 살리지 못했다는 한계를 갖는다. 그리고 이는 미 제 1 군단이 평양진격 간 일으킨 몇 가지 주목할 만한 전술적 과오로써 뒷받침될 수 있다. 첫째, 미 제 1 군단은 평양진격 간 공격 기세를 유지하지 못하고, 과도하게 시간을 지체하였다. 둘째, 미 제 24 사단을 평양진격에서 배제함으로써 전투력 집중을 달성하지 못하였다. 셋째, 북괴군의 퇴로 차단을 위한 포위 기동에 실패하였다. 이처럼 인천상륙작전 성공 이후 38도선을 회복한 유엔군은 평양탈환이라는 전략적 목표 자체에 집착함으로써 상급부대 작전에 기여하기 위한 지혜를 발휘하지 못하였다. 이러한 관점을 바탕으로 본 연구에 서는 '적 수도 탈환'이라는 영광에 가려진 평양탈환 전투의 이면(裡面)에 숨겨진 한계를 발굴해냄으로써 현재 에 대한 함의와 교훈을 도출해 낼 것이다.

주제어 : $6 \cdot 25$ 전쟁, 평양탈환 전투, 금천전투, 사리원 전투, 유엔군의 평양진격

* (제1저자) 육군교육사령부, 육군대학, 육군 소령, 151wkrwjs@gmail.com 